Max-Planck-Institut für demografische Forschung

Max Planck Institute for Demographic Research

Konrad-Zuse-Strasse 1 - D-18057 Rostock · GERMANY

Tel +49 (0) 3812081 - 0; Fax +49 (0) 3812081 - 202;

http://www.demogr.mpg.de

MPIDR WORKING PAPER WP 2006-011

APRIL 2006 (REVISED DECEMBER 2006)

\title{
Fertility change in Egypt: from second to third birth
}

Daniele Vignoli (vignoli@demogr.mpg.de)

This working paper has been approved for release by: Jan M. Hoem (hoem@ demogr.mpg.de)

Head of the Laboratory of Contemporary European Fertility and Family Dynamics.

(C) Copyright is held by the authors.

Working papers of the Max Planck Institute for Demographic Research receive only limited review. Views or opinions expressed in working papers are attributable to the authors and do not necessarily reflect those of the Institute. 


\title{
FERTILITY CHANGE IN EgYPT: FROM SECOND TO THIRD BIRTH
}

\author{
Daniele Vignoli \\ Department of Demography, University of Rome "La Sapienza" (Rome) \\ European Doctoral School of Demography at the Max Planck Institute for Demographic Research (Rostock)
}

\begin{abstract}
This work focuses on Egypt, a country that notwithstanding its advanced stage of sociodemographic transition has shown near stagnation in the reduction of fertility levels in the last decade. The progression from second to third birth is a crucial component in fertility change, since the reduction especially of third and higher-order births maintains the fertility decline. For this reason, the study aims at analyzing the main determinants of the third-birth intensities of Egyptian two-child mothers, applying an event-history analysis to the 2000 Egyptian Demographic and Health Survey. The study's results show that fertility differentials among the country's social groups continue to persist. Moreover, the difficult change in the fertility of women with high educational standards seems to be responsible for the stalling fertility decline during recent years. The analysis, however, has demonstrated that within the framework of the ongoing process of modernization in the country, even the most laggard groups of women showed a decrease in third-birth intensity during the 1990s. The study also reveals that the preference for at least one son in the family on the progression to the third child is weakening among women who have completed secondary education.
\end{abstract}

\section{Introduction}

The fertility patterns of the South-East Mediterranean shore are very different from those of the lowest-low fertility countries of the Northern shore (Courbage 1994, 1999, 2001; Mencarini and Salvini 2003). Recently, however, we are facing a decline in fertility levels in all countries of the former region (Figure 1).

Is the image we have of this area (apart from Turkey) as a bastion of family conservatism and as a region of high fertility still applicable today? After all, in some countries of the Southern shore of Mediterranean region, women with a high level of 
education who live in an urban area have a period TFR below the replacement level. Are these groups of educated and urbanized women forerunners of a wide and generalized spread of fertility decline or do they merely represent a plurality of behaviors in increasingly heterogeneous societies on the balance between tradition and modernization?

The paper focuses on Egypt, a country that is nowadays characterized by a decline in fertility levels and by important changes in the intermediate determinants of fertility, especially in urban areas (Giusti and Vignoli 2005, 2006).

If the first phase of the fertility transition has been generally marked by an increase in the age at marriage, in the long run the diffusion of the smaller family will play a major role in countries of advanced transition (Salvini 1997), such as Egypt. The progression from second to third birth, thus, is a crucial component in fertility change, since the reduction especially of third and higher-order births maintains the fertility decline (Feeney and Wang 1993). For this reason, the study aims at analyzing the main determinants of the third-birth intensities of Egyptian two-child mothers, applying an event-history analysis to the 2000 Egyptian Demographic and Health Survey (EDHS 2000) ${ }^{1}$.

Section 2 briefly provides a description of the fertility decline in Egypt. In the next section, the paper's research hypotheses and some descriptive results on the progression to third birth are presented. There follows in Section 4 a description of the data and methods used. The results are presented in Section 5. The final section summarizes and concludes the paper.

Figure 1 - Fertility trends in the Mediterranean area: a comparison between the northern and southern shores, TFRs.

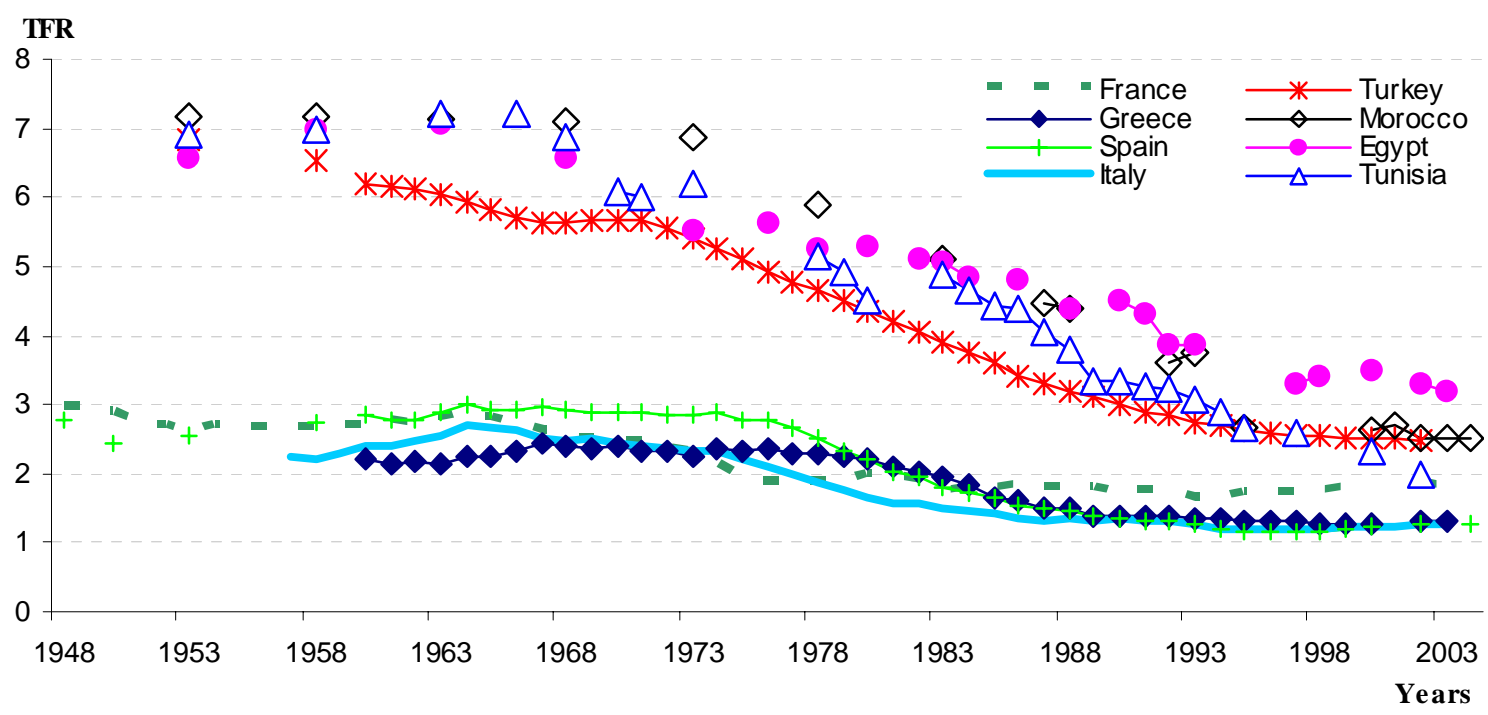

Source: Update on Mencarini \& Salvini, 2003.

\footnotetext{
${ }^{1}$ The most recent retrospective survey was conducted in Egypt in 2005 and the preliminary results just appeared - see http://www.measuredhs.com.
} 


\section{Fertility Decline in Egypt}

The estimated population of Egypt totals around 69.9 million inhabitants (CAPMAS 2005). The country is characterized by the presence of large families, by a population where more than half have no or little education (more than $60 \%$ of the women), and by an annual income per capita equal to as little as 1,200 (ICE, 2005).

The sustained fertility decline in Egypt began in the 1960s; nevertheless, in 2005 the Total Fertility Rate (TFR) was still higher than three births per woman (Figure 1). This is roughly half a birth above the current fertility level in Algeria and Morocco, and almost one birth above the level currently witnessed in Iran and Turkey. According to the Demographic and Health Surveys 1995-2003, the average number of children desired per woman (Wanted TFR) ranged between 2.5 and 3.0, with the most recent estimate at 2.6. The fertility level of the most recent decades has been decreasing from a TFR of 5.3 in 1980 to a TFR of 3.1 in 2005 (El-Zanaty and Way 2006). The fertility decline was particularly rapid in the 1980s; thus the drop in fertility was uneven throughout the last decade. Moreover, the fall in fertility did not affect all cohorts of fertile women to the same degree: While for women aged 30 and above age-specific fertility rates between 1980 and 2000 decreased by more than $40 \%$, fertility rates among women under age 30 declined by only about $25 \%$ during this period. In 2000, a woman with an average of 2.3 births by her 30th birthday, roughly two-thirds of her lifetime births (El-Zanaty and Way 2001). These tendencies have implications for future fertility in Egypt. If the young cohorts of Egyptian women will continue with delayed fertility, we can expect a decline in their Cohort Fertility Rate (CFR).

The marked decline in fertility in the 1980s (from 6 to 4 children per woman) is evident. The TFR stagnated in the 1990s, however, and this development recently has been subject to much discussion in the literature (Eltigani, 2003) ${ }^{2}$. Whereas studies based on interpolation techniques have highlighted a continuation in Egyptian fertility decline (Fargues 1997, UN 2003, US Census Bureau 2004), a study carried out by El-Zanaty and Way (2004) has revealed even an increase in Egyptian fertility levels during the 1990s. (See also Engelhardt 2004).

\section{The Theoretical Framework of Egyptian Fertility Transition}

The drop in fertility is now significant throughout the Islamic world (Courbage 1995) and it has been much faster in North Africa than in the Middle East, probably due to the greater exposure of the former region to Western models. The control of fertility in the French-speaking Maghreb countries seems to have been closely related to growing

\footnotetext{
2 Note that period measures such as the Total Fertility Rate used in this text are inevitably influenced by cohort developments, e.g. by changes in the mean age at childbearing. A recent study on the role of cohort effects in the Egyptian fertility shows that the "quantum" of fertility - as represented through measures adjusted for cohort effects - confirms the "stagnation" of fertility in Egypt during the decade 1980-1990 (Engelhardt 2004).
} 
living standards and to the expansion of education, sice the latter is becoming increasingly gender-equal (Mencarini, Salvini, and Vignoli 2006).

Education seems to remove the differences in fertility between the various countries; such differences, which continue to be high only for illiterate women, are still perceptible for women with a low to medium level of education, while they are negligible for the better-educated. From the first half of the 1990s, the average fertility of women with a high school certificate settled at generational replacement levels in all Arab countries (Fargues 2000).

Postponement of marriage is a central aspect that influences fertility levels in Muslim countries (such as Egypt). Here, almost all births occur within marriage. Marriage and childbearing are viewed as interrelated socio-demographic processes and as sequential phases in the female life-cycle. Thus, any increase in the age at first marriage constitutes an important demographic event (Eltigani 2000).

In Egypt, the impact of greater female access to education is significant. Education is related to later entry into both married life and childbearing: Girls who have completed secondary school are more likely to delay marriage and childbearing, their children tend to be healthier, and their participation in the labor force is relatively higher (UN 1995). There is a difference of more than five years in the median age at first marriage between women who have completed secondary education (23.2 years) and those who have never attended school (17.6 years). When they have their first child, highly educated women are also on average nearly five years older than women who never went to school (El-Zanaty and Way 2004). Thus, female education appears to play a major role in the course of fertility, regardless of the socio-economic level (see, among others, Castro Martin 1995).

Urbanization is another central aspect that influences women's reproductive choices: In urban areas, the socio-demographic transition and, more specifically, fertility transition is accelerated (Mencarini, Salvini, and Vignoli 2005). It has been widely shown that socio-economic structural change, mortality decline, changes in the domestic economy, costs associated with birth control, idea diffusion, and the relevance of social networks all have an impact that is stronger in urban areas than in rural areas (White et al. 2002). In Egypt, the region and the urban-rural type of residence (particularly if considered jointly) make for the greatest part of variability in contraceptive behavior, as they synthesize many contextual factors related to inequalities in the access to the structures of family planning (Giusti and Vignoli 2005, 2006).

Reproductive behavior is intimately related to the participation of women in the labor force. Many studies use female employment as a proxy for female status, expecially regarding access to financial resources, and this despite the fact that working women do not necessarily have control over their income. Courbage (1998) states that entry into the labor force (even if only at the blue-collar level) has a greater impact on fertility than enrolment in primary education. However, once fertility declines dramatically, the opportunity costs of children increases for working females, but the reproductive process occupies a shorter period of women's active lives, thereby allowing them to increase their participation in the labor force (Reher 2001).

Another factor that has an effect on a family's decision to have a child is possibly the sex of the child(ren) they already have or desire to have. The sex preference for children has been a prominent issue in demographic studies on reproductive behavior on developing countries since long time (e.g., Clark 2000, Arnold, Choe, and Roy 1998). 
The term son preference is usually used to refer to the attitude that sons are more important and more valuable than daughters. Extensive literature documents that in countries where the son preference is prevalent there exist a commonly accepted strategy to stop having children - selective birth control ${ }^{3}$. Practicing selective birth control makes for a negative relationship between the proportion of sons and family size (Clark 2000). Families who have a preference towards a son are likely to continue having children until they reach the desired number of sons (Dalla Zuanna and Leone 2001).

Evidence of the son preference is well documented for Egypt regarding fertility behavior, including contraceptive use (Arnold 1997). The son preference is often institutionalized, in particular in patriarchal societies (such as Egypt): Male progeny is wanted as males carry on the family line and the family name. Moreover, sons are often thought to enhance the power and prestige of a family. Male are usually favored over women owing to economic considerations: they can help out in the family business (Arnold 1997).

\section{Research Hypotheses and a First Glance at the Transition to Third Birth}

For above mentionated reasons, the present study focuses on the third-order fertility. Current individual data are analyzed in order to find out whether or not there are "pioneer" low fertility subgroups, such as women who have enjoyed higher education or who have been brought up in an urban area. If there are such groups, then we expect the status of women to have an impact on reproductive behavior, leading to differentials in the risks of third childbirth.

In other words, we are interested in verifying the hypotheses that postponement of marriage, an urban background, a higher educational level, and work experience each lead to a higher propensity of establishing smaller families. Moreover, we also expect the sex preference for children to have an effect on fertility, an effect that differs among the subgroups of the population.

A first glance at the progression to third birth in Egypt confirms the hypotheses above, showing significant variations in fertility behavior according to selected sociodemographic characteristics (Table 1; details on the data used are provided in the next paragraph): We observe differential behaviors according to the childhood place of residence, the educational level ${ }^{4}$, the employment status ${ }^{5}$ before marriage, and the sex composition of children. Women's education seems to play a key role in impacting the timing of third birth. The evidence is provided in Figure 2, which displays the Kaplan-

\footnotetext{
${ }^{3}$ Three mechanisms may affect the sex composition of children ever born: (1) biological factors; (2) sexselective abortion, provided the technology is available, (3) selective birth control - couples who have attained the desired sex composition of their children are more likely to cede having children.

${ }^{4}$ Education is included in the analysis on the assumption that women have completed their educational career at the time of second birth.

${ }^{5}$ Note, however, that many of the conventional measures of labour-force participation, obtained from survey questions hide a consistent proportion of women engaged in productive activity (Donahoe 1999).
} 
Meier survival curves for the transition to third birth by education. There is a strong similarity between the survival curves for those who have no education and those with primary education: Both groups started to reduce their fertility earlier compared to their counterparts of secondary and higher education. After the first five years, however, the gaps between the three curves start to narrow, although different behaviors by education continue to persist.

Table 1: Transition from second to third birth, according to some socio-demographic variables. Kaplan Meier survival curve estimates.

\begin{tabular}{|c|c|c|c|c|}
\hline $\begin{array}{c}\text { Socio-demographic } \\
\text { variables }\end{array}$ & $\begin{array}{c}\text { Women never having } \\
\text { experienced } 3^{\text {rd }} \text { birth } 5 \\
\text { years into the } 2^{\text {nd }} \text { birth } \\
(\%)\end{array}$ & $\begin{array}{c}\text { Women never having } \\
\text { experienced } 3^{\text {rd }} \text { birth } \\
10 \text { years into the } 2^{\text {nd }} \\
\text { birth }(\%)\end{array}$ & $\begin{array}{l}\text { Duration at which } \\
25 \% \text { of women } \\
\text { experienced third } \\
\text { childbirth (years) }\end{array}$ & $\begin{array}{l}\text { Duration at which } \\
50 \% \text { of women } \\
\text { experienced third } \\
\text { childbirth (years) }\end{array}$ \\
\hline \multicolumn{5}{|l|}{$\begin{array}{l}\text { Childhood place of } \\
\text { residence }\end{array}$} \\
\hline Rural & 17.2 & 6.4 & 1.7 & 2.5 \\
\hline Urban & 40.0 & 20.8 & 2.1 & 3.9 \\
\hline \multicolumn{5}{|l|}{$\begin{array}{l}\text { Women's } \\
\text { educational level }\end{array}$} \\
\hline No education & 11.6 & 3.9 & 1.5 & 2.2 \\
\hline Primary & 16.2 & 6.0 & 1.7 & 2.5 \\
\hline Secondary and higher & 38.1 & 18.1 & 2.3 & 3.9 \\
\hline \multicolumn{5}{|l|}{$\begin{array}{l}\text { Work experience } \\
\text { before marriage }\end{array}$} \\
\hline No & 18.1 & 6.9 & 1.2 & 2.6 \\
\hline Yes & 37.4 & 19.1 & 2.2 & 3.7 \\
\hline \multicolumn{5}{|l|}{$\begin{array}{l}\text { Children's sex } \\
\text { composition }\end{array}$} \\
\hline Two girls & 18.9 & 6.7 & 1.7 & 1.9 \\
\hline Two boys & 20.8 & 8.4 & 1.7 & 2.7 \\
\hline One boy and one girl & 21.9 & 9.6 & 1.8 & 2.7 \\
\hline
\end{tabular}

Source: Own elaborations based on DHS 2000, Egypt.

Figure 2: Kaplan-Meier survival curve estimates for the transition from second to third birth according to women's educational level.

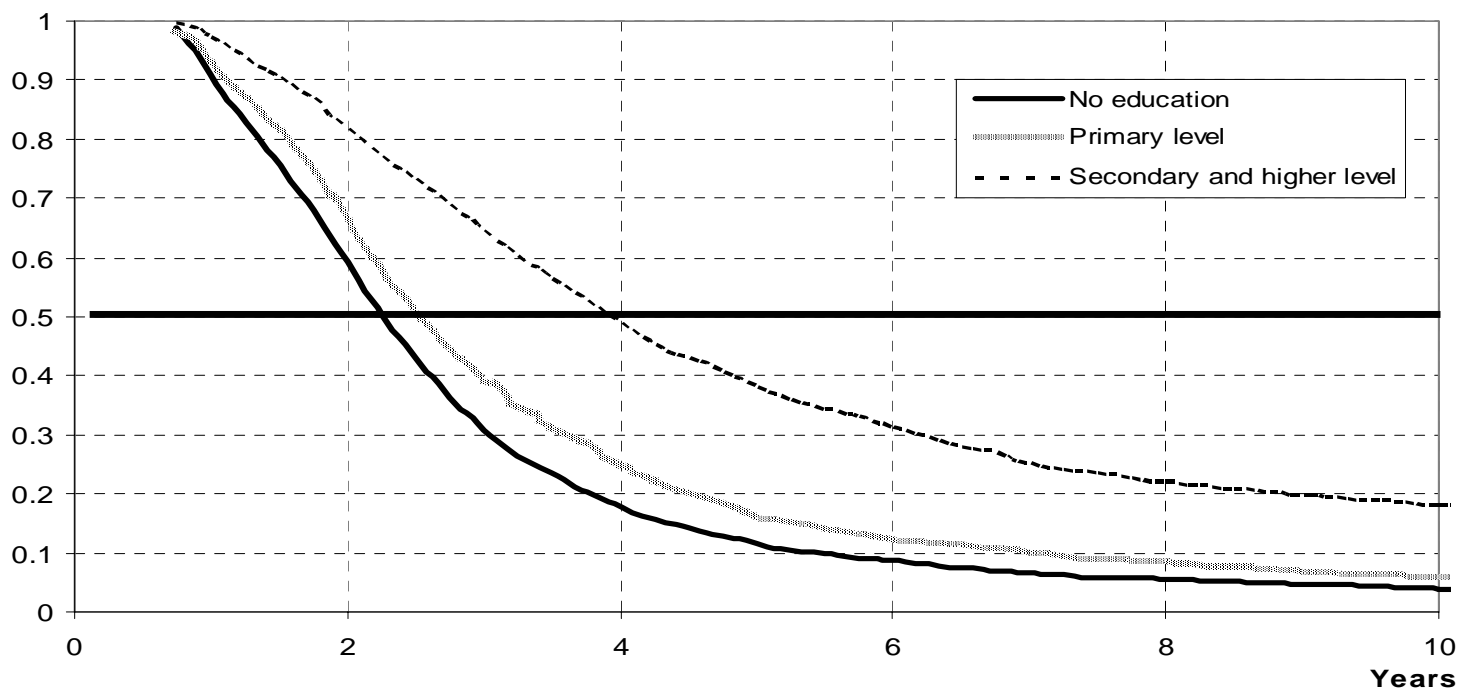

Source: Own elaborations based on DHS 2000, Egypt. 
To sum up, the simple descriptive outcomes above highlight the complexity of the situation studied. The transition to third birth apparently differs markedly among the population sub-groups (i.e. differentials related to education, ubanization, and labormarket participation).

\section{Data and Model Specification}

The descriptive analyses carried out so far do not allow for an evaluation of the role played by each explanatory factor (individual or context-related) at the "net" of the others. A model thus needs to be constructed, allowing us to investigate the factors that influence the progression to third birth in Egypt.

The data used refers to the Egyptian Demographic and Health Surveys 2000 (EDHS 2000). Being married is almost universal in Egypt and practically all births occur within marital unions. Our analysis therefore focuses on 10,274 currently married women aged 15 to 49 who have given second childbirth (excluding twins at second birth). The Egyptian Demographic and Health Survey includes a wide range of retrospective questions on birth histories and contraceptive use, but most of the background characteristics we need were not collected with the individual life histories (i.e. information on migration, employment, and the family cycle were obtained only at the time of the survey). Hence, it was impossible to examine these variables in conjunction with preceding births and to regard them as explanatory variables (Hoem 1996).

Some of the basic socio-economic and demographic characteristics of women are investigated, using a piecewise constant intensity regression model. Women's third-birth risk is defined as the probability of her experiencing third birth within the next month; given her individual characteristics and given that she has not given birth by the beginning of the month. The risks are assumed to be constant within each time interval but may vary across such intervals. The process time of the model is the number of months elapsed from the second to the third birth (starting eight months after the second child).

A time-varying covariate is included in the model specification so as to capture the influence of changes in the socio-political environment on third-birth intensity. The Egyptian family planning program has been witnessing continued growth ever since its introduction. Family planning services were first provided in the 1950 s by voluntary organizations. Five years later, eight experimental clinics opened to provide services to women: Access was restricted, however, requiring written approval from the husband. Furthermore, women were eligible only if they had a relatively large family and provided evidence that health problems or financial difficulties would arise should another child be born (Eltigani 2001). In the 1960s, the clinics multiplied and the restrictions were lifted (Fargues 1997). Coinciding with the establishment of the Supreme Council of Family Planning, the first planning program was launched in 1965 (Eltigani 2001). As a successor to the Supreme Council, the National Population Council was created 20 years later, to be followed by the creation of the State Ministry for Population and Family Welfare in 1993 (Ibrahim 1995). Three years later, the Ministry for Population and 
Family Welfare was abolished and a new Population Sector created instead within the Ministry of Health; the latter was renamed the Ministry of Health and Population. Recently, non-governmental organizations and private-sector services (physicians, pharmacies, private hospitals and clinics) have played an important role in the family planning services (Eltigani 2000), this in addition to the governmental facilities. To capture the effect of changes in the country's socio-political environment, we include three time periods of equal length in the model (1986-1990, 1991-1995, 1996 to the date of interview). This also serves the purpose of evaluating changes in the country's family planning policy.

We construct the following full model of multiplicative main-effects:

$$
h(t)_{k l m n o p r s}=a_{k(t)} b_{l} c_{m} d_{n(t)} e_{o} f_{p} g_{r} h_{s},
$$

where $h(t)$ is the third-birth intensity, which depends on various levels of factors, $a$ represents the basic time factor (the number of months elapsed since second childbirth), $b$ denotes the age at first marriage, $c$ the length of the previous birth interval, $d$ the calendar period, $e$ represents the women's childhood place of residence, $f$ their educational level, $g$ the husband's educational level, and $h$ the children's sex composition (a variable examining the three possibilities "two girls", "two boys", and "one boy and one girl"). The variables are grouped into categorical levels, indexed by $l, m, o, p, r$, and $s ; k(t)$, and $n(t)$ denote the intervals in which the baseline hazard and the calendar period are kept constant.

\section{Results and Comments}

The model parameters are presented in Table 3 in the form of relative risks, together with the p-value in order to evaluate the significance of each covariate's effect on third childbirth.

Postponement of marriage is associated with lower third-birth intensity: The latter diminishes by $34 \%$ when comparing women who married before they reached age 20 with women who married after age 26 . The close link between marriage and fertility in Egypt is attributable to the fact that in Muslim societies, marriage represents the only recognized institution in which childbearing is permitted (Eltigani 2000). However, in Egypt the average age at first marriage is still young (by both international and regional Mediterranean standards). In this sense, note that the postponement of first marriage has made a lesser contribution in the Egyptian fertility transition process than elsewhere in the Arab region (e.g. Morocco) ${ }^{6}$.

\footnotetext{
${ }^{6}$ Among the older generations (women born in 1960-71) the difference in the union patterns between Egypt and Morocco used to be negligible (age at marriage was around 17 years); differently, Egyptian women born in 1965-70 marry, on average, at the age of 20, while Moroccan women marry at 23.8 years (Mencarini and Salvini 2003).
} 
The length of the previous birth interval results in important (and significant) control covariate. Short intervals between the first and the second child are associated with lower transition rate from second to third birth.

Controlling for the calendar period, the first period has the highest progression risk and then the risk diminishes at each subsequent level. As to the last period, the risk is around $27 \%$ lower than it is for the pre-1990 period. The decline in third-birth fertility is thus evident for the fifteen years preceding the survey (1986-2000).

Table 3: Relative risks (and p-values) of third-birth intensities for two-child mothers, standardized by selected socio-demographic characteristics, Egypt 2000.

\begin{tabular}{|c|c|c|}
\hline Covariates & Relative Risks & p-value \\
\hline \multicolumn{3}{|l|}{ Age at marriage } \\
\hline Less than 19 years & 1.00 & - \\
\hline $20-22$ years & 0.86 & 0.000 \\
\hline $23-25$ years & 0.78 & 0.000 \\
\hline More than 26 years & 0.66 & 0.000 \\
\hline \multicolumn{3}{|l|}{ Previous birth interval } \\
\hline Less than 2 years & 1.00 & - \\
\hline 2 years and more & 0.56 & 0.000 \\
\hline \multicolumn{3}{|l|}{ Calendar period } \\
\hline $1986-1990$ & 1.00 & - \\
\hline 1991-1995 & 0.75 & 0.000 \\
\hline 1996-2000 & 0.73 & 0.000 \\
\hline \multicolumn{3}{|c|}{ Woman's childhood place of residence } \\
\hline Rural & 1.00 & - \\
\hline Urban & 0.72 & 0.000 \\
\hline \multicolumn{3}{|c|}{ Woman's educational level } \\
\hline No education & 1.00 & - \\
\hline Primary & 0.86 & 0.001 \\
\hline Secondary and higher & 0.65 & 0.000 \\
\hline \multicolumn{3}{|c|}{ Work experience before marriage } \\
\hline No Work experience & 1.00 & - \\
\hline Work experience & 0.93 & 0.070 \\
\hline \multicolumn{3}{|c|}{ Sex composition of previous children } \\
\hline Two girls & 1.00 & - \\
\hline Two boys & 0.95 & 0.005 \\
\hline One boy and one girl & 0.93 & 0.035 \\
\hline \multicolumn{3}{|c|}{ Duration since second birth } \\
\hline$<1.5$ years & 1.00 & - \\
\hline $1.5-2.49$ years & 3.35 & 0.000 \\
\hline $2.5-3.99$ years & 3.99 & 0.000 \\
\hline $4-5.99$ years & 3.21 & 0.000 \\
\hline $6-18.5$ years & 1.60 & 0.000 \\
\hline
\end{tabular}

Source: Own elaborations based on DHS 2000, Egypt.

As expected, the educational composition of the population, work experience before marriage, and the childhood place of residence all are important predictors of fertility change: Women with a lower level of education, those with no work experience preceding marriage and those who were brought up in a rural context experience a higher transition rate from the second to the third child. It thus emerges that in Egypt the diffusion of urban-type norms make crowded and complex household types less feasible 
to maintain ${ }^{7}$. Increasing educational standards, postponement of marriage, and rising proportions of women involved in economic activity all are aspects that are significantly changing women's reproductive choices. The experience of employment and a higher level of educational attainment enable them to be less dependent on their husbands and on extended family members. It follows that a greater degree of female independence decreases third-birth intensity (Yavuz 2005).

Looking at the sex composition of the previous children, we can see lower transition rate for couples who have "two boys" (i.e., a hazard which is lower by 5\%) and for couples who have "one boy and one girl" (i.e., a hazard which is lower by 7\%), in comparison with the reference category "two girls". These findings provide evidence for a moderate presence of the sex preference in $\mathrm{Egypt}^{8}$. Reproductive behavior is thus consistent with families' desire to have "at least one boy" to maintain the ancestral line, but no special desire for many boys is apparent.

In order to catch the process of fertility decline according to women's educational level, an interaction model is fitted between the calendar period and educational attainment (Table 4). The results reveal a general decrease in third-birth intensity over time at each educational level; this means that also women with a low level of education experienced a fertility decline during the 1990s. Another interesting aspect when comparing the last examined period (1996-2000) with the previous one (1991-1995), is the stagnation in the decline of third-order fertility for the better-educated women. This finding possibly contributes to explain the recent leveling off of Egyptian aggregate fertility. This result is in line with a recent work by Eltigani (2003). Using data collected by the 1988, 1992, 1995, and the 2000 Egyptian Demographic and Health Survey, the author states that the reproductive behavior of women from high and middle standard households is largely responsible for the stalling of the fertility decline during recent years.

A second interaction involves the calendar period and work experience preceding marriage (Table 5). The results show a decline in third birth intensity over time both for women with and without work experience before marriage. As for the previous interaction, even the latter groups show a drop in fertility during the last five years of the1990s.

Thus, the outcomes of the interaction between the calendar period and women's education and between the calendar period and women's work experience preceding marriage (Tables 4-5) do not support the main arguments generally presented in the demographic transition theory. Namely the changes are not concentrates in some socioeconomic strata, but all the segments of the population are changing their reproductive behavior. We found that dynamic process of modernization in the country impacts even the fertility behavior of the most laggard groups of women, highlighting the process of emancipation from the traditional role of wife and mother.

\footnotetext{
${ }^{7}$ Note, however, that the effect of modernisation in each specified area is not merely the weighted sum of the effect of relatively modernized women in that area: Women's choices are also significantly influenced by the specific context of residence (Giusti and Vignoli 2005, 2006), the latter which is influenced by the cultural norms of the community and by the particular opportunities that the area of residence has to offer.

${ }^{8}$ Analysis of the impact of the sex combination of previous children on all birth order until parity seven has been carried out so. In general, instead of a preference of sons over daughters, it emerges a preference for a gender equilibrium within the family. Details of these analyses - available from the author by request are not reported in the text being the progression to third child the key parity-transition also for this issue.
} 
The effect of educational attainment is also seen in the interaction between the sex composition of the children and the level of the mother's education (Table 6). Women with no education probably do not use contraception very much, and so they are unable to control their fertility. Although they may well prefer boys to girls, it does not matter what their sex preferences are since they cannot realize them. Hence the sex composition of their existing children has no effect on their future fertility.

The less educated portion of the population (with primary level of education) consists in women who probably use birth control and have a sex preference: When they have reached the desired sex composition, they are more likely to cede childbearing than those who have not yet done so.

Furthermore, the influence of the son preference tends to wane when looking at women who have completed secondary or higher education. This result underlines the important role that education plays in fertility: it removes selective birth control when it comes to the sex composition of the children.

Table 4: Relative risks (and p-values) of third-birth intensities for two-child mothers, by interaction between calendar period and women's educational level, Egypt 2000.

\begin{tabular}{lccc}
\hline & & Calendar period & \\
Women's education level & $1985-1990$ & $1991-1995$ & $1996-2000$ \\
\hline No education & 1.00 & $0.72(0.000)$ & $0.68(0.000)$ \\
Primary & $0.86(0.000)$ & $0.65(0.000)$ & $0.55(0.000)$ \\
Secondary and higher & $0.58(0.000)$ & $0.49(0.000)$ & $0.50(0.000)$ \\
\hline
\end{tabular}

Source: Own elaborations based on DHS 2000, Egypt. LR> $\chi_{4}^{2}(0.95)$

Note: The interaction is controlled for all the other factors presented in Table 3.

Table 5: Relative risks (and p-values) of third-birth intensities for two-child mothers, by interaction between calendar period and women's work experience before marriage, Egypt 2000.

\begin{tabular}{lccc}
\hline & \multicolumn{3}{c}{ Calendar period } \\
Work before marriage & $1985-1990$ & $1991-1995$ & $1996-2000$ \\
\hline No Work experience & 1.00 & $0.95(0.000)$ & $0.86(0.000)$ \\
Work experience & $0.91(0.079)$ & $0.82(0.006)$ & $0.76(0.000)$ \\
\hline
\end{tabular}

Source: Own elaborations based on DHS 2000, Egypt. LR> $\chi_{2}^{2}(0.95)$

Note: The interaction is controlled for all the other factors presented in Table 3.

Table 6: Relative risks (and p-values) of third-birth intensities for two-child mothers, by interaction between women's educational level and sex composition of previous children, Egypt 2000.

\begin{tabular}{lccc}
\hline & \multicolumn{3}{c}{ Women's educational level } \\
Sex composition of previous children & No education & Primary & Secondary and higher \\
\hline Two girls & 1.00 & $0.87(0.056)$ & $0.64(0.000)$ \\
Two boys & $0.95(0.188)$ & $0.72(0.000)$ & $0.62(0.000)$ \\
One girl and one boy & $0.93(0.257)$ & $0.71(0.002)$ & $0.61(0.000)$ \\
\hline
\end{tabular}

Source: Own elaborations based on DHS 2000, Egypt. LR> $\chi_{2}^{2}(0.95)$

Note: The interaction is controlled for all the other factors presented in Table 3. 


\section{Discussion}

Today, almost all countries of the South-East Mediterranean Region witness fertility transition. The widening of educational opportunities and urbanization is influencing reproductive behavior. Despite the limited presence of women in the labor market, an irreversible drop in fertility seems to prefigure considerable social transformations (the erosion of the patriarchal system and the modification of the societal status of women) (Fargues 2000, 2003).

Egypt of the last decade, notwithstanding its advanced stage of socio-demographic transition, has shown near stagnation in the reduction of fertility levels. This study analyzed the impact of some socio-demographic characteristics of Egyptian women on the propensity of third childbirth in Egypt. The findings show that the differences among the social groups continue to persist: Women with a lower educational level, a rural background, and women with no work experience preceding marriage display higher risks of third childbirth. The study also reveals that the preference for at least one son in the family on the progression to the third child is weakening among women who have completed secondary education.

The following question arises: What can we expect in terms of future Egyptian fertility? Stagnation in the decline of third-order fertility is observed among women who have completed secondary education. The difficult change in the fertility of women with high educational standards seems thus to be responsible for the stalling fertility decline during recent years. The analysis, however, has demonstrated that within the framework of the ongoing process of modernization in the country, even the most laggard groups of women showed a decrease in third-birth intensity during the 1990s. Thus, because women who had no schooling, who lived in rural areas and who had no work experience still represent a sizable proportion of the Egyptian population, we can expect a further decline in the number of large families in the near future.

As to the aggregate level of fertility, decreasing fertility will continue, if only as a result of the continuing trend towards greater education, urbanization, and work among women. According to the demographic forecasts made by Courbage (2002) for Egypt, the proportion of educated women is expected to grow in the short run and this fact in itself will continue to mean an increase in the average age at marriage and at first birth, and therefore also a decline of the period fertility rate. What the quantum of fertility will be in the long run when the rise of timing indicators ends is, of course, impossible to say.

\section{Acknowledgements.}

This project has been carried out during my stay at the Max Planck Institute for Demographic Research as a fellow in the European Doctoral School of Demography. I am grateful to Jan M. Hoem for his useful teaching during the Winter-Semester 2005/06. The work of Yavuz (2005) constituted a reading inspiration. I would like to thank Agata V. D'addato for the motivating exchange of opinions during the elaborations on the analysis. Silvana Salvini, Paola Di Giulio and three anonymous reviewers are gratefully acknowledged for their insightful and helpful comments. Susann Backer is acknowledged for the language editing of this paper. 


\section{References}

Arnold F. (1997). "Gender preferences for children". Demographic and Health Surveys Comparative Studies No.23.

Arnold F, Choe MK, Roy TJ. (1998). "Son preference, the family-building process and child mortality in IndiaC. Population Studies, 52 (3): 301-315.

Central Agency of Public Mobilization and Statistics (2005). Statistical Year Book 1996-2004. Cairo Egypt: CAPMAS.

Castro Martin T. (1995). "Women's Education and Fertility: Results from 26 Demographic and Health Surveys". Studies in Family Planning, 4.

CIA. http://www.cia.gov/cia/publications/factbook/geos/eg.html (last update 20 April 2005).

Clark S. (2000). "Son preference and sex composition of children: Evidence from India". Demography, 37 (1): 95-108.

Courbage Y. (1994). Demographic tradition among the Maghreb peoples of North Africa and in the emigrant community abroad. In: Ludlow P, editor. European and the Mediterranean. CEPS/Brassey's.

Courbage Y. (1995). "Fin de l'explosion démographique en Méditerranée". Population, no.1, Recherche.

Courbage Y. (1998). The demographic inflection of the southern Mediterranean: reasons for optimism". In Meijer R, editor. Alienation of Integration of Arab Youth. Curzon Press, Richmond, Surrey.

Courbage Y. (1999). "Nouveaux horizons démographiques en Méditerranée". Travaux et Documents, n. 142, INED, Paris.

Courbage Y. (2001). "Sur les pas de l'Europe du Sud: la fécondité au Maghreb". http://www.un.org/esa/population/publications/completingfertility/RevisedCourbagep aper.PDF.

Courbage Y. (2002). "New demographic scenarios in the Mediterranean region". INED, Paris.

Dalla Zuanna G, Leone T. (2001). "A gender preference measure: the sex ratio at last birth". Genus, 57(1) : 33-56.

Demographic and Health Survey - http://www.measuredhs.com (access: 30 June 2005).

Donahoe D. (1999). "Measuring Women's Work in Developing Countries". Population and Development Review.

El-Zanaty F, Way A. (2001). Egypt Demographic and Health Survey 2000. Ministry of Health and Population [Egypt]. Maryland: National Population Council and ORC Macro.

El-Zanaty F, Way A. (2004). 2003 Egypt Interim Demographic and Health Survey. Ministry of Health and Population [Egypt]. Cairo: National Population Council and ORC Macro.

El-Zanaty F, Way A. (2006). Egypt Demographic and Health Survey 2005. Cairo: Ministry of Health and Population, National Population Council, El-Zanaty and Associates, and ORC Macro.

Eltigani EE. (2000). "Changes in family-building patterns in Egypt and Morocco: a comparative analysis". International Family Planning Perspectives, 26 (2): 73-78. 
Eltigani EE. (2001). "Childbearing in Five Arab Countries". Studies in Family Planning, vol.32(1): 17-24.

Eltigani EE. (2003). "Stalled Fertility Decline in Egypt, Why?". Population and Environment, vol.25(1): 41-59.

Engelhardt H. (2004). Egypt's Stalled Fertility Decline and Possible Role of Tempo Distortions. In Lutz W, editor. Population Network Newsletter n. 36.

Fargues Ph. (1997). "State policies and the birth rate in Egypt: from socialism to liberalism". Population and Development Review, 23:115-138.

Fargues Ph. (2000). Générations arabes. L'alchimie du nombre. Paris: Fayard.

Fargues Ph. (2003). "La femme dans les pays arabes: vers une remise en cause du système patriarcal?". Population \& Sociétés, 387.

Giusti C, Vignoli D. (2005). Ricorso alla contraccezione in Egitto: tra scelte individuali ed eterogeneita' regionali. WP 2005/14, Florence: Florence University Press. http://eprints.unifi.it/archive/00001182/

Giusti C, Vignoli D. (2006), "Determinants of contraceptive use in Egypt: a multilevel approach". Statistical Methods and Application, 15(1): 89-106.

Hoem J.M. (1996). "The harmfulness or harmlessness of using an anticipatory regressor: how dangerous is it to use education achieved as of 1990 in the analysis of divorce risks in earlier years?". Yearbook of Population Research in Finland, n. 33.

Ibrahim S.E. (1995). "State, women, and civil society: An evaluation of Egypt's population policy”. In: Obermayer C M, editor. Family, Gender and Population in the Middle East: Policies in Context. Cairo: AUC Press.

ICE. http://www.ice.gov.it (last update 12 May 2005).

Mencarini L, Salvini S. (2003). "Mediterranean fertility: toward a South-North convergence?". Popolazione e Storia 2, Udine.

Mencarini L, Salvini S and Vignoli D. (2005). La fecondità nella Riva Sud del Mediterraneo: realtà urbana e rurale a confronto. Quaderni del Dipartimento di Statistica 2005/01. Firenze: Florence University Press. http://e-prints.unifi.it/archive/00000815

Mencarini L, Salvini S and Vignoli D. (2006). "Mediterranean fertility: similarities and differences between the two shores". Proceedings of conference "Espaces et Temps de l' Europe", Florence , 2-4 September 2004. Forthcoming.

Reher D. (2001). The demographic transition revisited. Paper presented at IUSSP Conference The History of World Population in the Second Millennium, Florence, Italy, June 2001.

Salvini S. (1997). Contraccezione e pianificazione familiare. Trasformazioni sociali e controllo della popolazione nei paesi in via di sviluppo. Bologna : Il Mulino.

United Nations. (1995). Women's Education and Fertility Behaviour: Recent Evidence from Demographic and Health Surveys. New York.

United Nations. (2003). World Population Prospects: The 2002 Revision, Vol. 1. New York.

US Census Bureau. http://www.census.gov/ipc/idbprint.html (last update 30 September 2004).

White JM, Tagoe E, Stiff C, Adazu K and Smith D. (2002). Urbanization and fertility transition in Ghana. 
http://www.brown.edu/Departments/Sociology/faculty/white/articles/urbanization_an d_the_fertility_transition_in_ghana.pdf)

Yavuz S. (2005). Fertility transition and progression to third birth in Turkey. Max Planck Institute for Demographic Research Working Paper, WP 2005-028.

http://www.demogr.mpg.de/papers/working/wp-2005-028.pdf 